\title{
Cutaneous and Gastrointestinal Helminth Parasites of the Fish Synodontis schall and Synodontis nigrita (Siluriformes: Mochokidae) from the Lower Ouémé Valley in South Benin
}

\author{
${ }^{1}$ Jacques Dougnon, ${ }^{2,3}$ Elie Montchowui, ${ }^{4}$ Florian Dadjo Daga, \\ ${ }^{1}$ Jédirfort Houessionon, ${ }^{3}$ Philippe Laléyé and ${ }^{5}$ Nestor Sakiti \\ ${ }^{1}$ Departement de Production et Santé Animales, Ecole Polytechnique d'Abomey-Calavi, \\ Université d'Abomey-Calavi, 01BP 2009 Cotonou, Republique du Benin \\ ${ }^{2}$ Ecole Nationale Supérieure des Sciences et Techniques Agronomiques de Ketou, \\ Université d'Abomey-Calavi, BP 95 Ketou, République du Benin \\ ${ }^{3}$ Laboratory of Hydrobiology and Aquaculture, Faculty of Agricultural Science, \\ Universite of Abomey-Calavi, 01BP 526 Cotonou, Republic of Benin \\ ${ }^{4}$ Département de Productions Animales, Faculté des Sciences Agronomiques, \\ ${ }^{5}$ Departement de Zoologie et Genetiqué, Faculté des Sciences et Techniques, \\ Universite d'Abomey-Calavi, 01BP 526 Cotonou, Republique du Benin
}

\begin{abstract}
Since, approximately 2 decades, there has been a regression of fish captures in Benin and particularly in the Basin of Ouémé river. A high parasitic infestation which would affect negatively the dynamics of the halieutic population, would be one of the probable causes of this regression. The present study aims to inventory helminth parasites in Synodontis schall and Synodontis nigrita from the lower Ouémé valley in South Benin and to estimate their prevalence. A sample of 75 specimens of the 2 fish species was examined at the laboratory between September and October, 2011. The results revealed high parasitic prevalence in the two species: 82.14 and $78.72 \%$, respectively. Six helminth genus were identified of which one digenean trematode (Clinostomum sp.), three nematodes (Cithariniella petterae, Procamallanus laeviconchus, Synodontisia thelastomoides) and two cestodes Stoeksia pujehuni and Lytocestus sp. Of the three parasites groups, nematodes are most abundant in both Mochokidae examined; they are 66.53 and $90.58 \%$ of parasites counted, respectively in $S$. schall and $S$. nigrita. Synodontisia thelastomoides has the highest prevalence: $46.43 \%$ in Synodontis schall and $42.55 \%$ in Synodontis nigrita.
\end{abstract}

Key words: Prevalence, helminth, parasite, Synodontis schall, Synodontis nigrita, lower Ouémé valley, Benin

\section{INTRODUCTION}

Synodontis schall and Synodontis nigrita are two catfishes species which, by their abundance in the lower Ouémé valley, contribute significantly to subsistence fishing (Laléyé et al., 2004; Laléyé, 2006). They breed annually in flooded plains when the river is in spate (Laléyé, 2006). In Benin, catfishes are very appreciated for food (Laléyé et al., 2004). They are the second most exploited fish group by artisanal fishing after Tilapias in Benin.

Since, approximately 2 decades, there has been a regression of fish captures in Beninese rivers and particularly in the basin of Ouémé river (Laléyé et al., 2007; Montchowui et al., 2008). Overexploitation of halieutic resources by the use of prohibited fishnets, river's pollution and the damage of aquatic environments by deforestation and hydro-agricultural substructures are the principal causes of this regression but bacteriological and/or parasitic diseases can be also considered as secondary cause.

Among diseases which affect fishes in natural environment, parasitic occur mostly. Parasitic diseases can affect growth, reproduction and other elements of the dynamics of natural host populations (Hudson and Dobson, 1989; Begon et al., 1992; Gbankoto et al., 1999, 2003; Simkova et al., 2001) but moreover they can sometimes lead to public health problems by means of zoonoses (Collier and Burk, 2002). Researches must thus be done in order to better control the parasitic diseases in

Corresponig Author: Elie Montchowui, Laboratory of Hydrobiology and Aquaculture, Faculty of Agricultural Science, Universite of Abomey-Calavi, 01BP 526 Cotonou, Republic of Benin 
aquatic populations. In Benin, few surveys has been carried out to list the parasitic diseases of catfishes in the aim to study their effect on various species of this fish group. Within this context, parasite inventory of fishes provides the basis for extensive researches on the system parasite-host. The present study relates to cutaneous and gastro-intestinal helminths of two catfishes belonging to the family of Mochokidae, Synodontis schall and Synodontis nigrita in the lower Ouémé valley in South Benin. Researchers aim by this study to widen knowledge about helminth parasites in Mochokidae of Benin.

\section{MATERIALS AND METHODS}

Study area: The present study was carried out in the lower Ouémé valley (between $10^{\circ} 00^{\prime}$ and $6^{\circ} 30^{\prime} \mathrm{N}$ ) in Benin. The Ouémé river, which length is $510 \mathrm{~km}$, takes its source in the mounts of Taneka and has two principal tributaries, Okpara $(200 \mathrm{~km})$ and Zou $(150 \mathrm{~km})$ rivers. Ouémé river crosses several agro-ecological zones and feeds downstream by a deltaic zone, the complex lagoon formed by the Lake Nokoue and the lagoon of Porto-Novo. The catchment area exceeds $50000 \mathrm{~km}^{2}$. Two different parts are distinguished in the basin: Higher and lower Ouémé.

The Ouémé river, while penetrating in the coastal sedimentary basin by the North-East of the plate of Zangnanado, receives its principal tributary Zou in latitudes of Pobé then hug the plateau of Pobé Porto-Novo before being thrown in the lagoon of Porto-Novo. The zone thus crossed constitutes the delta of Ouémé. Its relief allows the spreading out of water during swelling because it has a gentle slope.

Ouémé river's delta has the shape of an elongated triangle and measures $90 \mathrm{~km}$ from North to South. The lagoon of Porto-Novo is its southernmost part. The vast deltaic plain is limited by the swamps of the So river in the West and by the plateau of Pobé-Porto-Novo in the East. However, the real outlines of the delta are not very precise, its limits varies enormously with the swelling's importance. Its surface area varies according to the moment when the observations are made. The delta of Ouémé river is subdivided in three parts:

- The high delta, constituting its Northern part is an opened corridor in the argillaceous formations of the Cretaceous and the Eocene extending between $20-30 \mathrm{~km}$. It extends until the limit from Bonou where the middle delta starts

- The middle delta is approximately a $50 \mathrm{~km}$ long plain which extends from Bonou to Azowlissé after passing Adjohoun. The width is relatively uniform in this zone where it hardly exceeds $10 \mathrm{~km}$. The riverbed is sandy, the water is shallow in dry season and the banks are rather high. The study area, the village of Agonlin-Lowe is located in this part of delta
- The low delta begins from the downstream of Azowlisse where the valley widens abruptly up to $20 \mathrm{~km}$ and finishes with the Southern frontage where the river is thrown in the lagoon of Porto-Novo. There, the river is muddy, the water is deep even in dry season and the banks are low. The plain is easily flooded, low and remains marshy all the year. The middle delta and the low delta constitute the lower Ouémé valley (Fig. 1)

Fish sampling: A total of 75 fishes including $28 \mathrm{~S}$. schall of size between 56 and $142 \mathrm{~mm}$ (SL) and 47 S. nigrita of size between 82 and $178 \mathrm{~mm}$ (SL) were examined between September and October, 2011. Fishes were collected at the fishermen using bow nets and gillnets. Fishermen set nets of various meshes in the evening at 16 o'clock and they collect caught fishes the next morning between 7 and 10 o'clock. Bow nets were posed in flood zones during the swelling but they were controlled each day by fishermen. Fresh fishes were brought to the laboratory for data collection.

Data collection at the laboratory: Collected fishes were brought to the laboratory where they were identified in species level, labelled, weighted with an electronic balance (trademark Kern of precision $0.1 \mathrm{~g}$ ) and measured with an ichtyometer (standard and total length). A macroscopic observation of the skin was made with the eye, looking for any suspect element (cysts especially). Suspect elements, when observed, were taken and laid out between slide and cover glass, in a water drop, to be observed with a binocular magnifier and/or a photonic microscope. The fish digestive tract was entirely extracted and observed with a binocular magnifying glass from esophagus to the rectum. Identified helminthes were observed with photonic microscope. For parasites taxonomy, research of Paperna (1982) and Kabré were served as references. Samples of each parasite species were fixed in alcohol $70 \%$.

Expression of the results and data analyzes: Parasitic prevalence was calculated for each fish species, each parasite species and the parasite groups. Parasitic numerical abundance was noticed for each fish species, each parasite species and for the parasite groups.

In order to establish a correlation between the size (standard length) of fish and the prevalence, fishes were regrouped by size $\left(\mathrm{T}_{1}: 50-99 \mathrm{~mm}, \mathrm{~T}_{2}: 100-149\right.$ and $\mathrm{T}_{3}: 150-200 \mathrm{~mm}$ ). No $S$. schall specimen was classified in the class $\mathrm{T}_{3}$. Statistical test of $\chi^{2}$ or chi-square was used in order to test the effect of size on prevalence; the variable $\chi^{2}$ or chi-square was calculated according to the equation: 


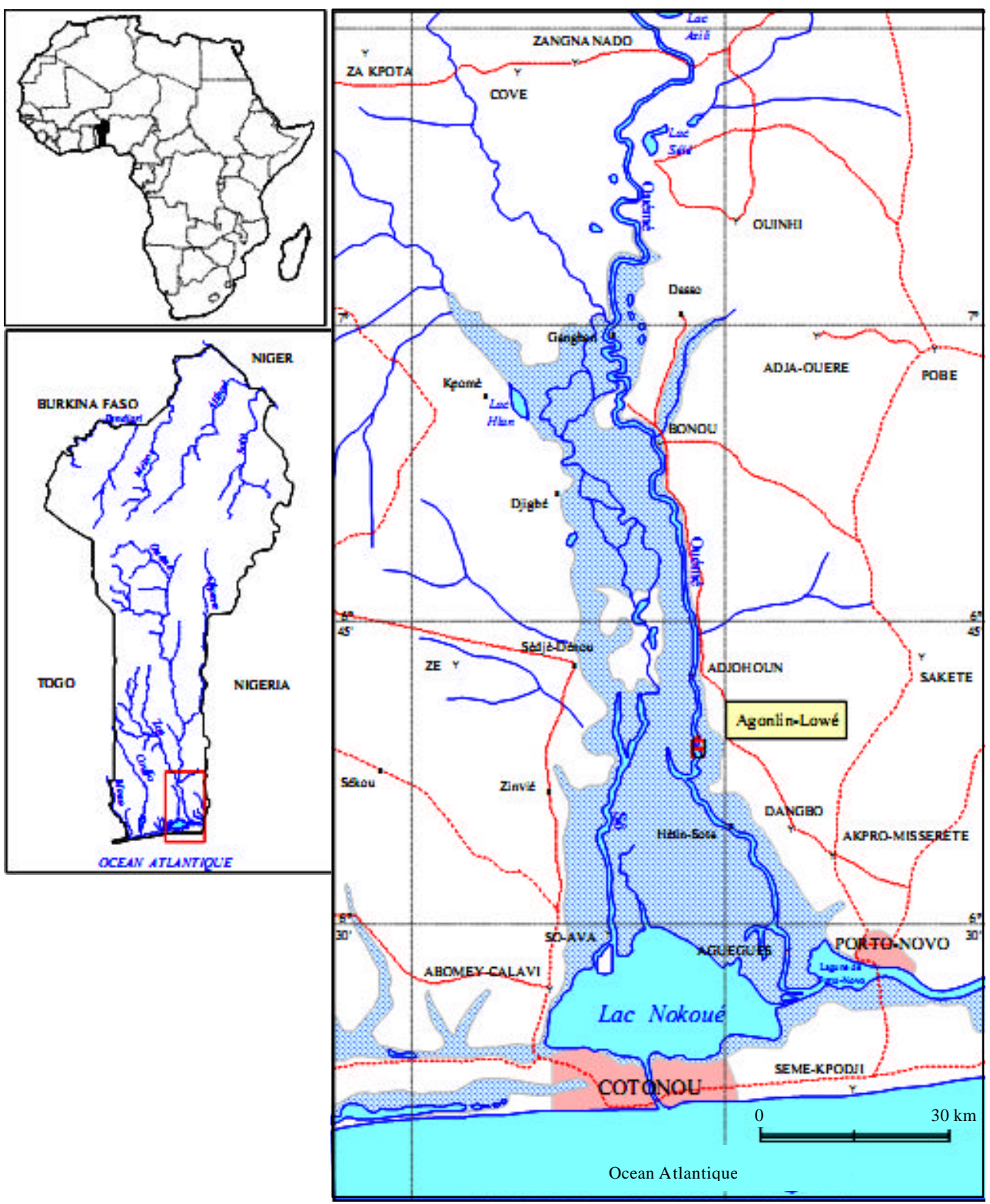

Fig. 1: Map of study area

$$
\chi^{2}=\sum \frac{\left(\mathrm{O}_{\mathrm{i}}-\mathrm{E}_{\mathrm{i}}\right)^{2}}{\mathrm{E}_{\mathrm{i}}}
$$

Where:

$\mathrm{O}_{\mathrm{i}}=$ Actual values

$\mathrm{E}_{\mathrm{i}}=$ Theoretical or awaited values

This calculated variable was then compared with a theoretical variable $\chi_{\text {theoretica, }}^{2}$ determined using a $\chi$ or chi-square table.

\section{RESULTS AND DISCUSSION}

Diversity of the helminthes: A total of 6 species of helminths belonging to four families (Clinostomidae, Lytocestidae, Camallanidae, Pharyngonidae) and six genus were identified during this survey. Clinostomidae are represented by the genus Clinostomum; genus Cithariniella and Synodontisia represent the family of Pharyngonidae and the genus Procamallanus represents Camallanidae while Lytocestidae are represented by genus Stoeksia and Lytocestus. 
Of six helminth, species observed, one was a trematode (Clinostomum sp.), two were cestodes (Stoeksia pujehuni, Lytocestus sp.) and three were nematodes (Procamallanus laeviconchus, Cithariniella petterae, Synodontisia thelastomoides). No acanthocephalan was recovered in examined fishes.

Clinostomum sp. occurred exclusively in skin where they are either free or encysted; cestodes were found only in the intestine while nematodes are parasites of the stomach and intestine. In two fish species, $P$. laeviconchus were found only in stomach. No parasites were recovered in esophagus.

Parasitic prevalence: The prevalence of parasitic infestation is $82.1 \%$ in S. schall and $78.8 \%$ in S. nigrita (Table 1). Collected data (Table 2) show that Synodontisia thelastomoides is the most prevalent specie (46.43 in S. schall and $42.6 \%$ in $S$. nigrita) while Lytocestus sp. is the least prevalent $(3.57$ and $6.4 \%$ in $S$. schall and $S$. nigrita). In $\mathrm{S}$. schall, parasitic prevalence is, respectively $67.9,32.1$ and $14.3 \%$ for nematodes, trematodes and cestodes while it is $66,23.4$ and $25.5 \%$ for S. nigrita (Table 3).

\begin{tabular}{lccc}
\multicolumn{4}{l}{ Table 1: Parasitic prevalence in fish specie } \\
Species & $\begin{array}{c}\text { Number } \\
\text { examined }\end{array}$ & $\begin{array}{l}\text { Number } \\
\text { infested }\end{array}$ & $\begin{array}{c}\text { Percentage } \\
\text { of infection }\end{array}$ \\
S. schall & 28 & 23 & 82.2 \\
S. nigrita & 47 & 37 & 78.7 \\
\hline
\end{tabular}

Table 2: Parasitic prevalence of parasites species

\begin{tabular}{lllrr} 
Parasites & Species & Host & $\begin{array}{c}\text { Infested/ } \\
\text { examined }\end{array}$ & $\begin{array}{r}\text { Percentage } \\
\text { of infection }\end{array}$ \\
\hline Trematode & Clinostomum & S. schall & $9 / 28.0$ & 32.2 \\
& & S. nigrita & $11 / 47.0$ & 23.4 \\
Cestodes & Lytocestus & S. schall & $1 / 28.0$ & 3.6 \\
& & S. nigrita & $3 / 47.0$ & 6.4 \\
& S. pujehuni & S. schall & $3 / 28.0$ & 10.7 \\
Nematodes & & S. nigrita & $9 / 47.0$ & 19.2 \\
& P. laeviconchus & S. schall & $9 / 28.0$ & 32.1 \\
& & S. nigrita & $14 / 47.0$ & 29.8 \\
& C. petterce & S. schall & $10 / 28.0$ & 35.7 \\
& & S. nigrita & $17 / 47.0$ & 36.2 \\
& S. thelastomoides & S. schall & $13 / 28.0$ & 46.4 \\
& & S. nigrita & $20 / 47.0$ & 42.6 \\
\hline
\end{tabular}

$\underline{\text { Table 3: Parasitic prevalence in parasites class }}$

\begin{tabular}{llcc} 
Host & Species & $\begin{array}{c}\text { Infested } \\
\text { examined }\end{array}$ & $\begin{array}{c}\text { Percentage } \\
\text { of infection }\end{array}$ \\
\hline Nematodes & S. schall & $19 / 28$ & 67.9 \\
& S. nigrita & $31 / 47$ & 66.0 \\
Trematode & S. schall & $9 / 28$ & 32.1 \\
& S. nigrita & $11 / 47$ & 23.4 \\
Cestodes & S. schall & $4 / 28$ & 14.3 \\
& S. nigrita & $12 / 47$ & 25.5 \\
\hline
\end{tabular}

Parasitic numerical abundance: A total of 493 helminth were collected from the 23 examined specimens of S. schall and 839 in the 37 infested specimens of S. nigrita. Cithariniella petterae is the parasite for which the two examined fish species have highest loads, 40.6 and $42.2 \%$ of helminth, respectively in S. schall and $S$. nigrita (Table 4 ). With regard to the parasites taxonomic classes, nematodes are more numerous, representing 66.5 and $90.6 \%$ of worms recovered respectively from S.schall and S.nigrita, while cestodes are only 1.2 and $2.7 \%$ of parasites in $S$. schall and $S$. nigrita (Table 5). Mixed infestation with the six kinds of parasites has been observed on only one fish specimen but often, hosts were infested by two or three various helminth parasites species.

Prevalence within host size: Table 6 shows the correlation of the helminth infestation with the standard length of $S$. schall and $S$. nigrita. In S. schall, groups $\mathrm{T}_{1}$ and $\mathrm{T}_{2}$ showed, respectively 73.3 and $92.3 \%$ of infestation; group $\mathrm{T}_{3}$ did not contain any specimen of S. schall. The parasitic prevalence does not vary significantly $\left(\chi^{2}=1.7, \mathrm{df}=1, \mathrm{NS}\right)$ according to $S$. schall's standard length. In $S$. nigrita, parasitic prevalence is $50,86.67$ and $100 \%$, respectively for $\mathrm{T}_{1}, \mathrm{~T}_{2}$ and $\mathrm{T}_{3}$ and they differ significantly with respect to the size $\left(\chi^{2}=8.39\right.$, $\mathrm{df}=2, \mathrm{p}<0.05$ ). Even if it seems that bigger fishes are more infested, there is no significant difference between the size group $\mathrm{T}_{2}$ and $\mathrm{T}_{3}\left(\chi^{2}=0.75, \mathrm{df}=1, \mathrm{NS}\right)$.

Most of studies (Sakiti et al., 1991; Gbankoto et al., $1999,2001,2003$ ) concerning parasites of fresh and brackish water fishes of Benin were devoted to Tilapias, the first group exploited by artisanal fishing. They often relate to Myxosporidians and Microsporidians. No survey has been devoted to the parasites of Beninese river catfishes in spite of their abundance and their economic function. This preliminary study on the helminth parasites of Synodontis schall and Synodontis nigrita is a first study carried out on the parasites of Beninese catfishes.

During this study, six species of helminth parasites belonging to four families and six genuses have been collected. These worms are trematodes, nematodes and cestodes.

Many researchers report the presence of metacercariae form of Clinostomum sp., in West African Cichlids. Ukoli (1965) and Olurin and Somorin (2006)

Table 4: Numeric abundance of parasites species

\begin{tabular}{|c|c|c|c|c|c|c|c|c|}
\hline Species & $\begin{array}{l}\text { Numeric } \\
\text { abundance }\end{array}$ & Clinostomum sp. & Lytocestus sp. & S. pujehuni & P. laeviconchus & C. petterae & S. thelastomoides & Total \\
\hline \multirow[t]{2}{*}{ S. schall } & Number & 159.0 & 1.0 & 5.0 & 37.0 & 200.0 & 91.0 & 493 \\
\hline & Percentage & 32.3 & 0.2 & 1.0 & 7.5 & 40.6 & 18.5 & 100 \\
\hline \multirow[t]{2}{*}{ S. nigrita } & Number & 56.0 & 5.0 & 18.0 & 184.0 & 354.0 & 222.0 & 839 \\
\hline & Percentage & 6.7 & 0.6 & 2.2 & 21.9 & 42.2 & 26.5 & 100 \\
\hline
\end{tabular}


which either by encysteding in the flesh or free on the gills in Oreochromis niloticus, Tilapia zillii and Sarotherodon galilaeus in Burkina-Faso. Siluriformes fishes infestated by Clinostomum sp., are sporadic. However, the results confirmed those of Onyedineke et al. (2009), who have observed in Nigeria the infestation of a Mochokids, Synodontis eupterus by Clinostomum sp. During this survey, no clinostomidae was found in the digestive tract. It is reported that when a man eats poorly cooked fish and infested by Clinostomum, there is a risk of laryngopharyngitis (Kabata, 1985).

Stoeksia pujehuni has also been found in S. schall and $S$. nigrita. Kabré has discovered it also but only in S. schall with a prevalence of $3.52 \%$. During this survey, the prevalence are 10.7 and $19.2 \%$ in $S$. schall and S. nigrita, respectively.

Several parasites belonging to the genus Lytocestus have been observed during other surveys on parasites of freshwater African fishes. However, infestations of these parasites in Synodontis were rarely observed. Baylis (1928) and Mahon (1954) reported, respectively the infestations of Lytocestoides tanganiyikae in Alestes sp., in Tanzania and of immature forms of Lytocestoides sp., in Parectodus sp., in Congo. Khalil (1973) has observed Lytocestus puylaerti in Clarias liberiensis in Sierra Leone; Kabré has reported the presence of Lytocestus sp., in the digestive tract of Clarias anguillaris in Burkina-Faso. Out of the African continent, infestations by parasites of the genus Lytocestus have been observed. Clarias batrachus infested by L. indicus (Woodland, 1926), L. longicollis (Rama Devi, 1973) and L. birmanicus and L. filiformis (Chakravarty and Tandon, 1988) has been recorded in India. The genus was also found in Burma (Lynsdale, 1956), on the island of Java (Furtado, 1963), in Malaysia (Furtado and Tan, 1973) and in Nepal (Singh, 1975). Kabré reported a prevalence of $19.6 \%$ in Clarias anguillaris, although during this survey, researchers observed prevalence of $3.6 \%$ in S. schall and $6.4 \%$ in S. nigrita.

\begin{tabular}{llcccc}
\multicolumn{6}{l}{ Table 5: Numeric abundance of parasites classes } \\
\hline \multirow{2}{*}{ Species } & $\begin{array}{l}\text { Numeric } \\
\text { abundance }\end{array}$ & Trematode & Cestodes & Nematodes & Total \\
\hline S. schall & Number & 159.0 & 6.0 & 328.0 & 493 \\
& Percentage & 32.3 & 1.2 & 66.5 & 100 \\
S. nigrita & Number & 56.0 & 23.0 & 760.0 & 839 \\
& Percentage & 6.7 & 2.7 & 90.6 & 100 \\
\hline
\end{tabular}

Procamallanus laeviconchus is a Pan-African parasite. There are many researchers (Khalil, 1970; Mashego and Saayman, 1981; Chishawa, 1991; Douellou, 1992; Yakubu et al., 2002; Barson and Avenant-Oldewage, 2006; Onyedineke et al., 2009) who reported it in various fish species (Schilbeidae, Mormyridae, Clariidae and Mochokidae) in African countries (South Africa, Nigeria, Zimbabwe, Burkina-Faso). Mashego and Saayman (1981) and Barson and Avenant-Oldewage (2006) counted, respectively 23 and 13 worms per infested fish. The present survey establishes a record of 122 worms on one $S$. nigrita specimen. The infestation prevalence of P. laeviconchus is 31.2 and $29.79 \%$, respectively in $S$. schall and $S$. nigrita, although Kabré has recorded a prevalence of $26.2 \%$ in S. schall.

Data on Pharyngonidae helminths are very few in West Africa. The genus Synodontisi was discovered by Peter et al. (1972) in two Mochokidae, Synodontis sorex in Senegal and Synodontis ocellifer in Chad. Kabré reported Synodontisia thelastomoides in S. schall in Burkina-Faso with a prevalence of $3.2 \%$. The researchers observed a prevalence of $46.4 \%$ in S. schall and $42.6 \%$ in S. nigrita. Cithariniella petterae has been reported with a prevalence of $3.3 \%$ in $S$. schall in Burkina-Faso while the results reveal 35.71 and $36.2 \%$ of instation in, respectively S. schall and S. nigrita. Other species, Cithariniella khalili was discovered by Peter et al. (1972) in other Mochokidae (Synodontis sorex in Senegal and Synodontis gambiensis latifrons in Tchad). Benin is then included in the distribution surface area of the Pharyngonidae.

The parasitic prevalence in examined two Mochokidae are high (82.2 and $78.7 \%$ in, respectively S. schall and S. nigrita). Almost all observed helminths are intestinal parasites. These two reports could be attributed to the sanitary conditions of the study area, the promiscuity between the river and the living place, people activities on the bank and more the omnivore nature of fishes examined. Highest prevalence has been recorded for Nematodes which are also the parasites for whom fishes have greatest parasitic loads.

When parasites do not induce host's death, the infestation tends to rise with time, leading to a higher prevalence and parasitic load in the oldest fish, i.e., which have greatest size (Lester, 1984). However, the prevalence did not vary significantly with the size in $S$. schall. Thus,

Table 6: Parasitic prevalence in relation with fishes Standard Lenght (SL)

\begin{tabular}{|c|c|c|c|c|c|c|c|c|}
\hline \multirow[b]{2}{*}{$\mathrm{SL}(\mathrm{mm})$} & \multicolumn{2}{|l|}{$50-99$} & \multicolumn{2}{|l|}{$100-149$} & \multicolumn{2}{|l|}{$150-199$} & \multicolumn{2}{|l|}{ Total } \\
\hline & S. schall & S. nigrita & S. schall & S. nigrita & S. schall & S. nigrita & S. schall & S. nigrita \\
\hline Examined & 15.0 & 12.0 & 13.00 & 30.00 & 0 & 5.0 & 28.00 & 47.00 \\
\hline Infested & 11.0 & 6.0 & 12.00 & 26.00 & 0 & 5.0 & 23.00 & 37.00 \\
\hline Prevalence & $73.3^{\mathrm{a}}$ & $50.0^{\mathrm{a}^{\prime}}$ & $92.31^{\mathrm{a}}$ & $86.66^{b^{\prime}}$ & 0 & $100.0^{b^{\prime}}$ & 82.14 & 78.72 \\
\hline
\end{tabular}

Values, of the same line for the same species which are not marked with the same letter are significantly different $(\mathrm{p}<0.05)$ 
recovered Clinostomum sp., in the intestine of tilapias in Nigeria. Coulibaly and Kabré reported their infestation it seems that the size does not have a significant effect on parasitism in the examined specimens of this species which could be the due to the randomization effect of the sampling. On the other hand, percentages of infestation in $S$. nigrita vary significantly with the size. Fishes with biggest size are more infested. The non significant difference between size groups $T_{2}$ and $T_{3}$ can be due either to the randomness of the sampling or to the mortality induced by a too high infestation of oldest fish which would be slightly represented in our sample.

Surveys conducted by Akinsanya et al. (2008), Onyedineke et al. (2009) and other researchers reported Mochokidae fishes infestation by other helminths belonging to genuses Paramphistomum, Bucephalus, Pomporhynchus, Wenyonia and Proteocephalus. None of these genuses has been observed during the observations. That can be explained by the fact that either the specimens of the study sample were not infested by those parasites or the parasites themselves are not living in Beninese rivers.

\section{CONCLUSION}

This study reveals a high parasitic infestation of fish by six species helminth parasites. Results obtained are certainly interesting; nevertheless, it remains that other aspects should be deepen in order to understand more the parasitic dynamics within the system fish-parasite.

\section{ACKNOWLEDGEMENTS}

Particular thanks are addressed to fishermen of Agonlin-Lowe village for their help during the sampling, especially Fidélé Hounsou and Toviho. The researchers do not forget examiners who made relevant and constructive critics.

\section{REFERENCES}

Akinsanya, B., A.A. Hassan and A.O. Adeogun, 2008. Gastrointestinal helminth parasites of the fish Synodontis clarias (Siluriformes: Mochokidae) from Lekki lagoon, Lagos, Nigeria. Rev. Biol. Trop., 56: 2021-2026.

Barson, M. and A. Avenant-Oldewage, 2006. One cestode and digenean parasites of Clarias gariepinus (Burchell, 1822) from the Rietvlei Dam, South Africa. Onderstepoort J. Vet. Res., 73: 101-110.

Baylis, H.A., 1928. LXVII.-Some parasitic worms, mainly from fishes, from Lake Tanganyika. J. Nat. Hist. Series, 1: 552-562.
Begon, M., J.L. Harper and R.C. Townsend, 1992. Ecology: Individuals, Populations and Communities. 3rd Edn., John Wiley and Sons, USA., ISBN: 13-9780632038015, Pages: 1068.

Chakravarty, R. and V. Tandon, 1988. On the present status of Caryophyllidea with a report of some caryophyllid infections in the freshwater catfish, Clarias batrachus (L.) in north-east India and a record of an anomalous form. Indian $\mathrm{J}$. Helminthol., 5: 37-54.

Chishawa, A.M.M., 1991. A survey of the parasites of three Siluriformes fish species in Lake Kariba. University of Zimbabwe, University Lake Kariba, Reserch Station Bulletin No 1/91.

Collier, D.N. and W.A. Burk, 2002. Pfiestaria complex organisms and human illness. South. Med. J., 95: $720-726$.

Douellou, L., 1992. A survey of fish parasites in Lake Kariba. Kariba: University of Zimbabwe, University Lake Kariba, Reserch Station Bulletin No 1/92.

Furtado, J.I. and K.L. Tan, 1973. Incidence of some helminth parasites in the Malayasian catfish Clarias batrachus (L.). Verhandlungen Int. Theor. Angwandte Limnol., 18: 1674-1685.

Furtado, J.I., 1963. A new caryphyllaeid cestode, Lytocestus parvulus sp. nov. from a Malayan cat fish. Annal Mag. Nat. Hist., 6: 93-106.

Gbankoto, A., N. Sakiti and A. Marques, 1999. Occurrence of a pathology linked to Myxobolus dahomensis (Siau, 1971), a Myxosporean parasite of wild and cultured Tilapia ovaries in Benin. J. Euk. Microbiol., 46: $14-14$

Gbankoto, A., C. Pampoulie, C.A. Marques and G.N. Sakiti, 2001. Occurrence of Myxosporean parasites in the gills of two tilapia species from Lake Nokoue (Benin, West Africa): Effect of host size and sex and seasonal patterns of infection. Dis. Aquat. Organ., 44: 217-222.

Gbankoto, A., C. Pampoulie, A. Marques, G.N. Sakiti and K.L. Dramane, 2003. Infection patterns of Myxobolus heterospora in two tilapia species (Teleostei: Cichlidae) and its potential effects. Dis. Aquat. Org., 55: 125-131.

Hudson, P.J. and A.P. Dobson, 1989. Population biology of Trichostrongylus tenuis, a parasite of economic importance for red grouse management. Parasitol. Tod., 5: 283-291.

Kabata, Z., 1985. Parasites and Diseases of Fish Cultured in the Tropics. Taylor and Francis Ltd., London, Pages: 318.

Khalil, L.F., 1970. On some nematodes from the freshwater fishes of Ghana with the description of a new species, Spironoura petrei n. sp. J. Helminthol., 46: 63-68. 
Khalil, L.F., 1973. Some Helminth parasites from African freshwater fishes with the description of two new species. Rev. Zool. Bot. Afr., 87: 795-807.

Laléyé, P., A. Chikou, J.C Philippart., G.G. Teugels and P. Vandewalle, 2004. Etude de la diversite ichtyologique du bassin du fleuve Ouémé au Benin (Afrique de l'Ouest). Cybium, 28: 329-339.

Laléyé, P.A., 2006. Length-weight and length-length relationships of fishes from the Ouémé River in Benin (West Africa). J. Appl. Ichthyolol., 22: 330-333.

Laléyé, P., A. Ezin, P. Vandewalle, J.C. Philippart and G.G. Teugels, 2007. Caracteristiques de la peche dans le fleuve Ouémé au Benin (Afrique de l'Ouest). J. Afrotrop. Zool., Special Issue 2007: 137-148.

Lester, R.J.G., 1984. A review of methods for estimating mortality due to parasites in wild fish populations. Helgol. Meeresunters, 37: 53-64.

Lynsdale, J.A., 1956. On two n. sp. of Lytocestus from Burma and the Sudan respectively. J. Helminthol., 30: 87-96.

Mahon, J., 1954. Contribution to the helminth fauna of tropical Africa: Tapeworms from the Belgian Congo. Ann. Mus. Belg. Congo, 5: 141-261.

Mashego, S.N. and J.E. Saayman, 1981. Observations on the prevalence of the nematode parasites of the catfish, Clarias gariepinus (Burchell, 1822), in Lebowa, South Africa. South African J. Wildlife Res., 11: 46-48.

Montchowui, E., P. Tobada, A. Chikou and P. Laleye, 2008. Caracteristiques et impact de la peche artisanale sur l'exploitation de Labeo senegalensis (Valenciennes, 1842) dans la basse vallee du fleuve Ouémé au Benin. Int. J. Biol. Chem. Sci., 2: 478-489.

Olurin, K.B. and C. Somorin, 2006. Intestinal helminthes of the fishes of Owa stream, South-Western Nigeria. Res. J. Fish. Hydrobiol., 1: 6-9.

Onyedineke, N.E., U. Obi, P.U. Ofoegbu and I. Ukogo, 2009. Helminth parasites of some freshwater fish from River Niger at Illushi, Edo State, Nigeria. J. Am. Sci., 6: 16-21
Paperna, I., 1982. Parasites, Infections et Maladies du Poisson en Afrique. Food and Agriculture Organization, Rome, Italy, ISBN-13: 9789252009825 , Pages: 202.

Peter, A.J., G. Vassiliades and P. Troncy, 1972. Trois espèces d'Oxyures parasites de Poissons en Afrique. Ann. Parasil. Hum. Comp., 46: 241-269.

Rama Devi, P., 1973. Lytocestus longicollis sp. nov. (Cestoidea: Caryyophyllidea) from the catfish Clarias batrachus (L.) in India. J. Helminthol., 47: 415-420.

Sakiti, G.N., E. Blanc, A. Marques and G. Bouix, 1991. Myxosporidies (Myxozoa, Myxosporea) du genre Myxobolus Butschli, 1882 parasite de Poissons Cichlidae du lac Nokoue au Benin (Afrique de l'Ouest). J. Afr. Zool., 105: 173-186.

Simkova, A., Y. Desdevises, M. Gelnar and S. Morand, 2001. Morphometric correlates of host specifity in Dactylogyrus (Monogenea) parasites of european Cyprinid fish. Parasitol., 123: 169-177.

Singh, S.S., 1975. On Lytocestus fossilis n. sp. (Cestoidea: Lytocestidae) from Heteropneustus fossilis from Nepal. In: Dr. B.S. Chauhan Commemoration, Vol: 1975, Chauhan, B.S., K.K. Tiwari and C.B. Srivastava (Eds.). Zoological Society of India, India, pp: 79-82.

Ukoli, F.M.A., 1965. Preliminary Report on the Helminth Infection of Fish in the River Niger at Shagunu. In: Man-Made Lakes, Obeng, L.O. (Ed.). The Accra Symposium, Accra, Ghana, University Press for Ghana Academy of Sciences, pp: 269-283.

Woodland, W.N.F., 1926. On the genera and possible affinities of the Caryophyllaeidae: a reply to Drs. O. Fuhrmann and J.G. Baer. Proc. Zool. Society London, 96: 49-70.

Yakubu, D.P., E. Omoregie and J.W. Wade, 2002. A comparative study of gut helminthes of Tilapia zilli and Clarias garipeinus from River Uke, Plateau State, Nigeria. J. Aqua. Sci., 17: 137-139. 